\title{
Juxtapositions in Jakarta: How Flood Interventions Reinforce and Challenge Urban Divides
}

\section{Roanne van Voorst ${ }^{1}$ if}

Published online: 1 July 2020

(C) The Author(s) 2020

\begin{abstract}
This paper traces the interplay of spatially, socially and legally juxtaposed differences between different groups of Indonesia's residents: (1) a group of riverbank settlers in Jakarta, (2) political decision-makers and urban planners that evict this particular riverbank settlement and (3) a group of Jakartan academics, architects and journalists that got involved in these interventions. The dynamics between and within these groups are examined through a case study in a riverbank settlement, where inhabitants are not only at risk of regular flooding but also of evictions. The analysis combines the notion of juxtapositions with a 'revelatory approach' towards disaster. The notion of juxtapositions makes clear how urban divides are shaped, and how they, in turn, produce ideas and practices of citizenship in Jakarta. The revelatory approach to disasters helps to show that floods can function as an accelerator to both reinforce and challenge these juxtapositions, thus also changing citizenship ideas and practices. The analysis reveals on the one hand that floods and interventions deepen socio-economic inequalities in an already highly unequal city. However, on the other hand, they also trigger collective mobilisation of evictees as well as unprecedented cooperation between this particular group of riverbank settlers and more resourceful members of Jakarta's wider society. This eventually results in successful contestation of evictions through court and other claims to citizenship.
\end{abstract}

Keywords Jakarta $\cdot$ City-making $\cdot$ Urban flooding $\cdot$ Eviction $\cdot$ Citizenship

\section{Introduction: Juxtapositions in and a Revelatory Lens on Jakarta}

This paper aims to contribute to the theorising of urban citizenship in the global South by drawing attention to the everyday politics of citizenship struggles and city-making practices of unregistered, poor riverbank settlers in Jakarta. These slum dwellers are

Roanne van Voorst

vanvoorst@iss.nl

1 International Institute for Social Studies, Erasmus University, The Hague, The Netherlands 
threatened by a dual risk: regular flooding, and the threat of evictions - the latter are commonly presented by policymakers as flood interventions.

The article offers a description of the power struggles that exist in Jakarta, by exploring a case in which different types of urban divides - called juxtapositionsare sometimes reinforced, and other times challenged, blurred or penetrated. In order to shed light on these dynamics, the article traces the practices of different groups of Jakartan residents that are, all for different reasons, involved in the issues of flooding and evictions. These groups are (1) riverbank settlers threatened by both floods and flood responses (evictions), (2) policymakers that develop and implement interventions around these issues and (3) a fragmented group of more resourceful inhabitants of Jakarta that seek to support riverbank settlers in their resistance against evictions. ${ }^{1}$

Analysing the dynamics between and within these groups, I combine an emphasis on juxtapositions with a revelatory approach to disaster (Solway 1994). In line with other papers in this special issues, juxtapositions or juxtacities refer to the side-bysidedness of, and productive interaction and friction between, differences within the urban social, economic and spatial environment (De Boeck and Plissart 2004; Appadurai et al. 2008; Simone 2010; Hammar and Millstein 2016). The notion of juxtapositions enables me to recognise, investigate and understand the dynamic qualities of multiple urban divides in Jakarta.

The revelatory lens or approach is inspired by the work of Jaqueline Solway in Botswana, who showed how a drought allowed for a shift in communal entitlements and hierarchies (Solway 1994, p. 472). Solway argues that these social dynamics were not arbitrary. Instead, the crisis of a drought accelerated dynamics that were already in progress, laid bare the patterns and, in addition, disrupted conventional routine sufficiently to allow actors to undermine normative codes and create new ones (Solway 1994, p. 471). Similarly, I argue that floods have created and still deepen social, spatial, and legal divides between different groups of Jakartan citizens: primarily a group of poor, unregistered slum inhabitants on the one hand, and political decision-makers, architects and planners on the other. Floods thus expose and deepen these juxtaposed differences in the city of Jakarta, but at the same time they offer a temporary chance for individuals and groups to create social change. As disasters like floods shake up daily routine, they open up room of manoeuvre for actors to change things in the society. In this particular case, they enable a challenging of ideas on citizenship, and blur distinctions between what is considered legal and illegal, rightful and unjust, and formal and informal.

Hence, we might say that the disaster of flooding provides an enlarging lens that offers a better insight into the way in which juxtapositions are produced within and

\footnotetext{
${ }^{1}$ One referee of this paper rightly commented that I do not specify the members of all three groups, in equal manners, and that I do not write much about the internal dynamics, or the heterogeneity within each group. This is true, particularly for the third group — which is a highly heterogeneous group of Indonesian and foreign citizens. While I am well aware that such fragmented category should, perhaps, not be lumped into a 'group' (One could question: are they not simply active individuals, rather than group members? And might it not be possible that group members overlap, for example when a policy maker (group 2 in my analysis) with an architect background also becomes involved in drafting urban plans that concern this particular neighbourhood (which different members in group 3 did)). I acknowledge this problem but nevertheless find it relevant for the analyses to roughly speak of three groups that interconnect, intermingle and influence one another. As I wrote elsewhere, though, each social group or community is always highly heterogeneous, and this needs to be acknowledged in any analyses - including in my own.
} 
between the actors in my case study. This combined approach helps to unpack and understand everyday urban citizenship.

The narrative about the risk of floods and evictions that follows this introduction reflects multiple juxtapositions of both materially distinct infrastructures and classbased forms of life and livelihoods. Examining these intersecting divides as active and productive spaces, as prompted by the juxtacities approach, provides insights into how authorities aim to shape the city and citizenship according to a modernist ideal and, most particularly, deal with informal spaces and residents that do not fit into this view. At the same time, the analysis (provided after the case introduction) shows how the power of authorities is challenged by poor residents, after they receive support from a group of more resourceful academics and other city inhabitants. This support was triggered after the issue of floods and evictions was highlighted in Indonesian media. It eventually enables poor residents to contest the views of authorities and claim space and rights in the city that challenge such views.

The analysis of this paper shows the various and dynamic ways in which Jakarta's urban poor claim rights. In doing so, the article sheds light on the underlying factors that influence acts of urban citizenship. Later in this paper, I will argue that although citizenship is traditionally understood as an assemblage of rights and obligations tied to its membership to a state, it goes well beyond legal ascriptions of nationality. It constitutes an enactment of political subjectivity that involves the claiming of rights and the right to have rights. According to Abdoumaliq Simone (2011: 359), urban citizenship is 'the practice of remaking notions of urban life itself'. This remaking of life is a constantly evolving, messy and fairly unpredictable process. It might be useful to envisage the city as a space, in which many various agents are constantly negotiating the usage of this space, as well as their economic, social and political rights in this space. By constant contesting, cooperating, challenging, influencing and negotiating, 'various agents are able to make claims on, for and through urban space' (Cohen and Margalit 2015: 668).

This paper shows that the described struggle by urban poor to claim basic rights is partly fraught by external factors - a specific context of poverty, plus a dynamic political context. Moreover, the act of claiming rights is influenced by internal factors-in this case, the changing, inner experiences of slum dwellers, who, through cooperation with more resourceful and powerful actors, turn into more knowledgeable and self-confident activists. This latter point is extremely relevant for an analysis on rights-making, as 'existing literature on urban citizenship...tend to focus on external factors that contribute to the rights-claiming struggle, such as structural and spatial factors... Only a few delve into the everyday lives of urban poor themselves, and their organisations' (Savirani and Saedi 2017: 180).

Therefore, this paper tries to explicitly take notice of the everyday practices by which the urban poor, and the organisations that represent them or try to support them, claim rights. These practices may include negotiation, protest or insurgency, seeking of favours, pity, reciprocity and clientelism (Bénit-Gbaffou and Oldfield 2014 , p. 487). In this line of thinking, this paper is heavily influenced by authors such as Holston (2008) and Chatterjee (2004), whose analytical views on citizenship went way beyond a limited interpretation of formal citizen participation. They showed that for many people in this world, especially people in the South, these formal routes are not accessible nor the most effective. Thus, by focusing on 
everyday practices of citizenship, rather than (only) on practices that may be easily recognized as being 'political' or follow formal or traditional pathways towards inclusive decision-making, I want to draw attention to (also) more informal practices by which citizens try to participate in decision-making, claim space or rights. However, as this case will make clear, my analysis in fact also includes formal citizen participation. It shows that slum dwellers do not stick to only alternative practices of citizenship; instead, they use a variety of all sorts of practices that may help them claim their rights to space.

The case of Jakarta thus sheds light on the complexity and messiness of everyday urban politics, in a context of disaster and poverty. Jakarta is an illustrative case of such complexity. On the one hand, it is a city that is not only highly unequal in an economic sense - with pro-elite and neoliberalist housing policies marginalising hundreds of thousands of slum dwellers, and with an estimated $60 \%$ of Jakarta's population living in low-income areas. It is also as a city that is run by state and corporate actors, whilst average citizens (among which, most obviously the city's poor masses) typically tend to be excluded from decision-making processes (Hellman et al. 2018). Over the past decades, hundreds of thousands of slum dwellers have been evicted from unregistered neighbourhoods, often built alongside rivers. In most recent years, this happened despite political promises by the former governor and later president Jokowi, and related high expectations of civic society that Indonesia's political system would become more inclusive, as well as protective of the poor. It also happened despite the fact that Jokowi was able to facilitate a relatively open political atmosphere (Savirani and Saedi 2017: 186). This paper will offer one case in which such promises were made and broken, but for now it is useful to get a broader idea of the political context in which this occurred.

Before he ran for president in 2014, in his 2 years of Jakarta governance, Jokowi promised a different approach to the urban poor. He did so in a period where elections were becoming more direct, and, as a result, it was becoming more important to win broad popular support. He sought cooperation with several civic and urban poor organisations to mobilise communities and win votes (Törnquist and Djani 2017: 121). In exchange, overt promises were made to these organisations and communities, including the promise that poor communities would be protected from evictions from land belonging to state-owned enterprises. In this exchange, some civic society and urban poor organisations managed to strike favourable deals with their new, populistoriented leaders (Törnquist and Djani 2017: 121). As Törnquist and Djani (2017) remark in their analysis of Jakartan and Indonesian politics, 'Jokowi projected himself as being in favour of direct links with popular and civic partners in society, rather than party bosses and their clienteles' networks' ( $p$ 127). However, in the years that followed, he wasn't able to effectively introduce new leadership, nor to stick to promises made to the urban poor. This was due to the fact that Jakarta's civic and popular partners were relatively weak to start with (as compared to the situation in Solo, where his policies had been more successful), plus the fact that Jokowi's government was unable to foster them. It also had to do with the fact that Jokowi, once in office, gave priority to transactional politics (through clientelist/populist relations), primarily within the elite. By the end of 2016, the government was rightly accused of neglecting the plight of the poor (Törnquist and Djani 2017: 122), and tens of neighbourhoods had been evicted - with more to come. 
Whilst evictions have been framed by authorities as a much-needed disaster response that should avoid further flooding, critics point out that the increasing intervention in Jakarta's urban form reveals a desire to exert greater control over the city's space. This is seen as suiting the modernisation agenda of Jakarta's middle class and elite to 'clean up' or 'develop' the city's slums (Simone 2010). The form this 'development' takes is moulded by modernist planning ideals, which shape the ways in which the Indonesian government sees the 'ideal city' and, most particularly, spaces of informality: as spaces of disorder, anarchy, dirt and criminalisation.

However, on the other hand, it is by no means the case that people in informal areas have no say in how the city is 'being made' (Simone 2010). Indeed, squatters and street sellers, as well as civil society and grassroots organisations have always been important and decisive in shaping Jakarta's spatial and socio-economic environments (Simone 2010; Hellman et al. 2018; Hellman 2015; Wilson 2015). Hence, whilst it is true that there exist social, spatial and legal divides in the city, these divides are sometimes blurred and, to some extent, penetrable. Through practices of citizenship and through negotiating and claiming, or simply by living, working and using Jakarta, even the urban poorest are often able to create and recreate 'cityness' (Simone 2010).

This paper pays explicit attention to the 'blurry', penetrable divides between formal and informal spaces. It shows that flooding interventions reproduce or even deepen already-existing inequalities, but it also shows that riverbank settlers' contestation of these policies eventually leads to a rebalancing of urban power. Furthermore, the paper seeks to show that whilst resisting citizenship practices of riverbank settlers can be and sometimes are related to formal institutions and a national state, this is by no means always the case. This finding is in line with what other scholars before me have concluded: as the urban poor typically defy policies imposed on them from above, they often get access to resources and environments not just through formal institutions, but also through resistance and insurgency. Indeed, as Miraftab and Wills (2005, p. 287) note, 'when formal channels fail, the poor use extremely innovative strategies, which create alternative channels and spaces to assert their rights to the city, negotiate their wants, and actively practice their citizenship'. The paper thus describes several innovative strategies that Jakarta's poor use to claim space and citizens' rights, most notably the right to housing. However, as noted, the paper goes beyond these 'alternative' strategies and also sheds light on several occasions in which these poor inhabitants have been able to claim space and rights through formal channels and more traditional strategies of citizenship.

Citizenship literature, traditionally, sprang from a (Western) idea that citizenship is defined through membership in the state and a national community and through formal institutions. This idea has been challenged through new forms and practices of urban citizenship, observed in cities all around the world. Similarly, early work on (Western) citizenship has been contested by academics whose thinking stretches beyond a limited interpretation of formal citizen participation, instead drawing attention to the ways in which urban space, rights and citizenship are being negotiated and claimed particularly in the global South (Chatterjee 2004; Holston 2009, 2011; Yiftachel 2012; BénitGbaffou and Oldfield 2014; Millstein 2017). Over the past decade or so, an increasing body of work has thus shifted its focus beyond the historical embeddedness in Western experiences. It has focused rather on the politics of urban citizenship in other parts of the world, which shapes residents' access to resources and more broadly the 
construction of their urban citizenship, including everyday practices of negotiation, protest, seeking of favours, pity, reciprocity and clientelism (Bénit-Gbaffou and Oldfield 2014, p. 487). This paper builds upon the work of these scholars. My analysis aligns, for instance, with the observations of James Holston $(2009,2011)$ and others, that whilst ongoing urbanisation has worsened poverty and inequality in cities worldwide, the struggles of low-income or otherwise marginalised residents for the basic resources of daily life and shelter have also generated new types of citizenship, with people claiming rights to resources, rights to the city and rights to rights (Bénit-Gbaffou and Oldfield 2014).

The data on which the following narrative is based were collected during long-term anthropological fieldwork in the research area conducted by the author between 2010 and 2015. Further data was derived up until June 2019 through maintained personal contact with respondents: visits from and to former respondents, follow-up phone interviews and informal chats through social media channels.

\section{Case: Flooding Interventions in Jakarta and Collective Counteraction}

During an afternoon in the rainy season, in the riverbank settlement where I had conducted fieldwork for nearly a year, a neighbourhood foundation called Ciliwung Merdeka organised yet another community meeting. Since commencing work on the riverbanks after a large flood in 2000, a group of volunteers has been involved in offering aid to flood victims, free medical services and education to slum dwellers and training among the riverbank inhabitants. More recently, the foundation has focused on the issue of eviction: tonight, the plan was to discuss the newly announced plans of the government to clear the riverbanks and come up with a counter proposal that included a demand for alternative housing or financial compensation. However, as had been the case during former meetings, the turnout was very low-only a handful of residents showed up. The foundation leader expressed to me that he had few means to mobilise more people, as he was only assisted by five volunteers, and 'people here don't realize that we are all in the same boat. Each individual has his own concerns, that is why they don't show up in group meetings like this and this is also why it is hard to effectively protest the threat of eviction without (adequate) compensation.'

One year later, the situation had turned around. During a community meeting organised by the same organisation, so many people showed up that there was insufficient space on the floors of the building - people stood up straight or sat out in the street. Over twenty volunteers were involved in the foundation, and, together with the visitors, they were engaged in a heated discussion about the eviction plans. Soon, their first court case would be filed. 'We are a compact group now', said the foundation leader. 'Together, we are strong and we have a chance to win this case'. In fact, they would - something that was unprecedented in Jakarta's history of evictions and slum dwellers.

What had happened, in the months between the two meetings?

One factor that contributed to collective action had to do with the fact that, after a new governor was elected, the number of evictions had vastly increased. A few weeks after the first meeting (the one where hardly anyone showed up), a neighbourhood that was located exactly opposite from my research area was evicted; one month later, yet 
another one followed, then one more. The evictions occurred without clear warnings to the residents, and in seemingly unnecessarily violent ways (Hellman et al. 2018).

Secondly, the strategy of the foundation had changed. Whilst the founder and his volunteers were initially merely focused on trying to involve residents in their activities, they had started to more actively engage the media in their plight. They invited foreign academics and local journalists to the neighbourhood to draw attention to their story. This had some success; a number of Indonesian journalists reported about the threat of eviction in local newspapers, and after a visit of Malay academics, tens of their (international) colleagues signed a petition protesting against the eviction plan and supporting the NGO.

Thirdly, some of these and other academics, myself included, published autonomous articles and blogs about the worsening, interrelated issues of floods and evictions. The foundation volunteers then spread the articles through social media- they were shared by hundreds of academic and non-academic readers. Later that month, I wrote another article with another colleague on the evictions. ${ }^{2}$ Other academics coupled up to write about land rights and social injustice (cf. Hellman et al. 2018; Holderness and Turpin 2015; Shepherd 2015).

Fourth and inspired by the growing attention of journalists, academics and other outsiders to their neighbourhood, the Ciliwung Merdeka foundation started a WhatsApp group about the evictions, and added their media and academic contacts as members. The group grew like a snowball. On the first days, it was just the six employees of Ciliwung Merdeka. Then academics joined in, among them myself but also former visitors and their colleagues who had been involved. Several employees of other Jakartan NGOs said yes to invitations and became members. Several lawyers, specialised in human rights and land rights, joined in as well. An architect became a member. An urban planner. Another architect. Another lawyer. Eight journalists that were drawn to the news of evictions became members. Most importantly, tens of riverbank settlers joined in as well, and the discussion grew increasingly active: on average, about 100 messages per day were exchanged.

Being a member of this WhatsApp group, I was able to follow the discussion. It ranged from Gramscian theories about power and oppression (written by academics); to proposals for countering the governmental plans (written by NGO volunteers and responded to by academics and activists); to questions about what could be done (riverbank settlers); to explanations (by architects) about the demands for alternative, sustainable housing; to discussions among everyone about how to engage the media and get journalists on 'our' side. Policy reports were shared; newspaper articles were copied and shared; critical cartoons and jokes about politicians were circulated. This already suggests that most members of the WhatsApp group were somewhat educated - they were at least able to read and write, which left out some of the elderly

\footnotetext{
${ }^{2}$ In this regard, it is important to consider that my own positionality shifted on the spectrum from research towards activist research. However, during the period in which I was conducting long-term fieldwork in Jakarta, I wasn't as much 'activist' as in later years. I was initially still so much occupied with, and fascinated by, understanding what was going on, that I kept busy with interviewing people, reading policy documents and observing daily life, that there remained little mental space for taking an overt position in the dynamics, myself. After fieldwork, this changed - I felt for 'my' residents, was horrified by violent evictions in this and other neighbourhoods and found a sense of frustration relief in writing articles about the social injustice being done.
} 
Java immigrants living in the neighbourhood, who'd often worked as children and did not go to school. It also left out the younger children. Most members ranged between the ages of 17 and 50, and I had the impression that the amount of males and females was about equal — although I did not actively test this. The most active members, who had their voices heard most often through messages and comments, were members who in the earlier days already cooperated with the $\mathrm{NGO}$ as volunteers or participants in projects.

The news that slum residents shared a WhatsApp group with outsiders beyond their neighbourhood, and engaged in critical and lively conversation, spread through Jakarta and again attracted more attention. New members joined-total strangers, people from outside the neighbourhood, even from outside the city. At this point, it became impossible for me to understand who were the active members of the group, as I did not know most of these new users. The Ford Foundation offered a grant to Ciliwung Merdeka and the Ciliwung Institute if they would cooperate to organise a community map of their respective neighbourhoods - they did so, with the help of several young academics that were members of the WhatsApp group. Several politicians who had been invited to the group agreed to meet and discuss with prominent members of the group. Governor Ahok even became a member, as did President Jowoki. They agreed to meetings with local representatives of the neighbourhood, who presented their counter-proposals for housing. More and more journalists visited the riverbank settlements and published articles about the inhabitants' demands and concerns. When I was visiting the neighbourhood two years ago, thirty Singaporean students and their professors were visiting the NGO and the neighbourhood - they were participating in a project on land rights and flood interventions, and were writing articles in which they took the side of the riverbank settlers.

With the help of an architect and several academics, Ciliwung Merdeka then started to facilitate weekly gatherings in the communities, during which residents were asked for input for a possible design proposal to counter the city's resettlement plan. As a standard, these were attended by tens of residents. In this process, they were assisted by architecture students, a design consultant and one of Jakarta's most famous architects, who wanted to volunteer. Ciliwung Merdeka also collected documents that the residents owned and that provided some form of evidence that they had built their houses themselves, bought them (and had proof of this) or had users' rights because they had been living there for long time. A map of the land status was presented to the Governor in the summer of 2015. Follow-up conversations with politicians followed in 2015 and 2016. Finally, they created an alternative proposal for social housing, complete with sketches and budgets. In this proposal, they were helped by a rather famous architect from Jakarta as well as by urban planners working for a city government advisory board. They had all recently become members of the WhatsApp group. The lawyers established a case to prove that riverbank settlers have land rights and cannot be evicted - for this, they were interviewing riverbank settlers, whom they could access through the network of the NGOs (The Jakarta Post 2015a, b).

The riverbank settlers hung banners with protesting texts such as 'this is our neighbourhood; if you want to evict it, pay us for it!!'. Many of them seemed to have taken over the human rights discourse that was commonly used by NGO employees and lawyers in the WhatsApp group. They would say, for example, that it was their 'civil right' to live at the river banks, and that the government has 'the responsibility to 
care for us'. This type of language I had never heard during the years that I lived and worked in the neighbourhood. 'It's like a contract between the state and society, you see,' explained one of my younger informants, to my amazement. Others used the arguments of the environmental NGO - underlining the damage that an eviction would do to the biodiversity. Again, this was something I had never heard anyone do during the former years.

However, these dynamics could not halt the evictions. During his two-year reign, Governor Ahok evicted thousands of families and businesses as part of flood management interventions. In 2016 alone, Ahok's administration evicted 5726 families and 5379 businesses - almost all of the evictees were poor and much of their livelihoods were destroyed because of the eviction. Most of them did not receive any or adequate compensation for their losses, meaning that they fell deeper into poverty. Whilst a minority was offered alternative housing in subsidised apartments, it appeared that the rents were much more expensive and also further located from markets. This led people deeper into poverty (Hellman et al. 2018).

Opposing the flood/eviction policy, 93 evictees from the neighbourhood under study filed a class action with the Central Jakarta District Court on May 10, 2016, and demanded compensation amounting to Rp 1.07 trillion (US\$73.8 million) in material losses and Rp 104 billion in immaterial losses. This class action was led by Ciliwung Merdeka and its leader, Sandyawan, who was again supported by over twenty local volunteers, as well as by several academics, lawyers, architects, urban planners and other members of the WhatsApp group. The Jakarta High Court judges ruled in favour of evictees' class action lawsuit opposing their eviction from their houses, and rejected an appeal filed by one of the defendants, the governmental Ciliwung-Cisadane Flood Control Office (BWSCC).

At the moment of writing, the money has only been paid out to a few evictees and not all. One reason is bureaucracy and re-elections, another is that opponents have tried to get the case redressed at Higher Courts (personal communication Sandyawan; personal communication employee A.G. of the World Bank, March \& October 2018). This makes it unsure whether the initial mobilisation of the urban poor will indeed translate into longer term transformative change. When Törnquist and Djani wrote in 2017 that 'the uneven growth and shallow democracy in Indonesia may foster counter movements', and that these would be based on 'citizens' demands for equal civil, political and social rights' (120), at the same time they asked whether such counter movements would be effective in fostering social democratic development. One of their answers to this question was rather sceptical, suggesting that the result of countermovements has been 'patronage in exchange for political support, rather than the facilitation of active citizenship in which people would get to know their rights and how they could claim and extend them' (129). In this particular eviction case in Jakarta, it cannot be denied that something similar may turn out to be true as most citizens did so far not manage to claim their rights to housing and compensation.

However, it seems also true that citizens have, in fact, gotten to know their rights and have learned how to claim them through different practices. Firstly, the victory has already been used as an example for other court cases by other activists, working in other neighbourhoods. Moreover, the new alliances that were formed have continued to working together, in other parts of Jakarta where communities are also threatened by evictions. During the last time I visited Jakarta (March 2020), it appeared that Ciliwung 
Merdeka, the NGO working in my research area, had set up office in another neighbourhood, was working with more paid and unpaid employees and was actively preparing new actions and court cases. Finally, the WhatsApp network has led to positive exchanges and the sharing of information between lawyers, academics and citizens - accumulating knowledge and a sense of empowerment among riverbank settlers.

Some of my informants mentioned that they are learning so much through the WhatsApp discussions about how to understand society or how to communicate with media; others pointed out that they feel strengthened emotionally just by the fact that politicians and journalists are finally hearing their side of the story. 'From now on,' said my former neighbour, 'I know how to protest more effectively against the government. I will no longer be afraid to approach politicians or journalists. Or to make a court case. I will just do it if I want to make my case clear - I have their phone numbers anyhow. And I will no longer be fooled by claims that I am illegal and have no right to housing or compensation. I have learned about my rights as a citizen'. Similar narratives were expressed by many other informants.

\section{Analysis: Urban Divisions and the Right to Space}

The case of flood interventions in Jakarta shows the myriad and complex ways in which an urban space is divided. Some of the juxtapositions highlighted in this paper are spatial, such as the divides between unregistered, informal, poor housing and planned, formal and middleclass neighbourhoods. Others are economic, like the different material circumstances of elite and poor residents. It was shown that flood interventions often reinforce or even worsen these spatial and economic divides. Through floods, as well as through evictions, slum dwellers lost their houses and fell deeper into poverty. For the moment that is, it might still be that slum dwellers win a court case and receive the compensation that, according to some key players involved in the legal cases and, most importantly, according to themselves, they have a right to.

This points to yet another juxtaposition highlighted in this paper: the one related to legal divides, such as the right to live in a house without being evicted without compensation, versus the lack of these rights for people in unregistered, informal neighbourhoods. The case shows that here, floods and flood interventions did not reinforce or deepen these divides. Instead, because floods and evictions drew media attention, and because this media attention again triggered the interest and pity of resourceful outsiders, legal divides between recognised citizens with rights to housing, and unregistered inhabitants without rights to housing, were challenged.

Finally, it became clear that there exists a juxtaposition between citizens' roles in society, and the ways in which they are able to claim space and rights. Most clearly, the case emphasised a divide between the decisions made by urban planners and other authorities, who appear active and whose positions stem from a neoliberalist modernisation agenda, versus the citizenship practices of slum dwellers, which appear reactive and were initially driven by the wish to defend their resources and well-being. Later, after cooperation with activists and other outsiders, they would be additionally motivated by the felt sense of justice to 'get what we - as citizens - have a right to'. Similar to my observation around legal divides, this juxtaposition seemed penetrable and 
blurred. Evolving practices around evictions transgressed previous divides between groups of residents (poor slum dwellers, versus more resourceful citizens). Through slum dwellers' engaging with mediating brokers such as journalists, NGOs, Human Rights activists, academics and urban planners, ideas and practices around citizenship started to shift. We might also say that the information exchange between different, formally divided groups challenged the informal/formal juxtapositions that existed. It also influenced ideas and practices around citizenship. This, again, shows that juxtapositions are divisions that are always in tension. They are relational, in the sense that they can only exist as long as they are not challenged, and hence, dynamic.

In summary, so far, the revelatory approach has helped me to show that floods offer different actors a means to push different agendas. Whilst evictions are often portrayed by urban planners as flood responses, needed to safeguard the city against rising water, in reality, they help authorities to mould Jakarta into a modern and clean city. They reinforce economic divides, in that way. However, the issue of floods and evictions offer slum dwellers opportunities, too. As these two problems increasingly gain attention in the media, wider support for the problems faced by evictees grows, too. As such, evictees become aware of, and supported in their struggle for, citizen rights. Floods and evictions thus point to ongoing battles, not only about access to urban space but also to meanings of what urban space and urbanity should be. Ultimately, these are struggles over urban citizenship, power and belonging.

If a revelatory lens shows the dynamics that come into play after shocks such as floods and evictions temporarily disrupt routines, the notion of juxtapositions helps to zoom in on these dynamics, and sheds light on what is produced through them. The paper reflects an interest in urban divides as generative space, where the concept of juxtapositions helps to reveal their productive qualities and effects. In the case of Jakarta, the notion of juxtapositions has helped decipher the ways in which former divides between citizens of planned/formal areas versus inhabitants of unregistered/ informal neighbourhoods were increasingly blurred through the process of eviction described in the above narrative. Whilst floods and evictions can and do reinforce divides, in this case, they also challenged them because the ideas and practices of slum dwellers about citizenship changed in the process.

\section{Claiming Citizenship}

Different scholars have tried to grasp alternative ideas and practices of city-making of urban poor in Southern cities. For example, Chatterjee (2004) proposes an analytical distinction between, on the one hand, a 'civil society' that is idealised, restricted to an elite group of residents who use the discourse and principles of individual rights, and, on the other, what he terms 'political society' or a 'politics of the governed'. The two latter terms refer to the majority of residents who cannot rely on full citizenship because of their informal status in one part of their life or another, particularly in their relationship with the state. In his analysis, the majority of people living in 'political society' therefore need to use brokers, and are dependent on the (reciprocal and/or clientelistic) assistance of politicians to mediate with legal and administrative public structures and actors. 
Likewise, James Holston describes what he calls insurgent urbanism and insurgent citizenship; these being the creative ways of the urban poor of claiming space and rights in a city where they are marginalised. These citizenship practices may include 'performances' like entering shopping malls or other spaces typically used by the middle class, or engaging in music or a way of talking to another citizen in a way that would be considered bold. Whatever it is exactly that is being performed here, suggests Holston, the behaviours can be regarded as coping strategies in response to the neoliberal policies that the urban poor have to defy. He refers to the citizenship he observes in urban Brazil as 'differentiated citizenship'. This is because, in terms of its formal and substantive principles of organisation, it uses social differences that are not the basis of national membership - primarily differences of education, property, race, gender and occupation - to distribute different treatment to different categories of citizens.

Abdoumaliq Simone offers more concrete examples of 'alternative' practices of citymaking and citizenship that are used by the urban poor. He has argued that the urban spaces of big cities like Jakarta and Dakar have been shaped to a considerable extent by the incremental claiming of space by the residents of the city's poorest, often unregistered areas (Simone 2010). Poor residents build their own (illegal) houses and establish various services: sanitary and waste disposal facilities, small markets, kiosks, small food stalls, tailoring street stalls and motorcycle taxis. This incremental way of shaping urban space proceeds without regulation and it benefits from the fact that formal, staterun urban planning has been ad hoc and erratic. Many areas have been left outside of urban planning agendas and have been able to develop organically, though local residents and users of these areas live with constant uncertainty about the future.

The case of Jakarta reflects these alternative practices of city-making, but also points to another finding, implicitly mentioned earlier in this analysis: the fact that slum dwellers claimed space and rights through formal pathways, like court cases. Hence, the paper goes beyond descriptions such as 'insurgent' or 'alternative' citizenship practices, and rather takes as a point of focus all the everyday citizenship practices of the urban poor - these appear to be a mixture of formal and informal, traditional and innovative practices. With an increasing number of evictions carried out in the city, it became easier for a local NGO to draw more attention of journalists, academics and other outside actors for their case. The involvement of these middle-class and relatively powerful outsiders, again, drew more interest from local residents to engage with them in conversations and meetings. These interactions, furthermore, also stirred a realisation amongst the potential evictees in the neighbourhood under study that they were 'in the same boat' and needed to be 'compact' and work together, in order to make a strong case. Eventually, this relatively powerless, fragmented group of people was able to win an important case for financial compensation after resettlement. Residents' access to financial compensation for their loss of housing, and more broadly the construction of their urban citizenship, was shaped by everyday practices of protest, negotiation with politicians, seeking of favours and socialising with media, academics and other influential actors (Bénit-Gbaffou and Oldfield 2014, p. 487).

For riverbank settlers, up until that point, many of the citizenship practices were new, most notably the use of a formal legal institution. But due to the set of events described in this paper, they have become familiar with these institutions and-having gained knowledge, a supportive network, self-confidence and increased trust in these institutions - they may take the same route some other time. This points to a tipping of 
the power balance. Without under-emphasising the deep divide between elite and poor, urban planner and 'unregistered' resident, and formal and informal, it also seems likely that these divisions have become slightly more blurred. A next eviction might, for example, face harder protest, as other slum dwellers may remember the success of this court case, accomplished by the ones described in this paper. Judges will recall the decision of this pioneering case, and may judge others in a similar way. And slum dwellers themselves will be able to build upon the network, education and experiences that they have gone through during this described eviction procedure. That means that it will get harder, and potentially more expensive, for city authorities to implement their modernist agenda.

Clearly, whilst flood mitigation interventions have reinforced social, spatial and environmental inequality in the city, they are not just damaging for vulnerable people. Instead, I argue that they also offer an opportunity for structural changes in society. The evictions in the neighbourhood under study, and the collective action around them, set in motion a collective and partly successful court action of slum dwellers. Their contestation of urban legal divides would eventually lead to empowerment and-to some extent — social justice. What was formally regarded by both slum dwellers and urban planners as an acceptable division between formal/informal, planned/ unregistered and rights-to-housing/no-rights-to-housing was now suddenly challenged by slum dwellers. Moreover, they were supported by resourceful outsiders, and a judge. Hence, these juxtapositions became blurred. Whilst it seems unrealistic to predict that the resisting practices of slum dwellers might also lessen economic divides between the poor and the elite, there still exists a chance that some residents are granted fair compensation for their lost houses, so that evictions will at least not lead to a deepening of economic inequality.

\section{Conclusion: New Ideas and Practices of Citizenship}

This paper aimed to contribute to the theorising of urban citizenship in the global South by drawing attention to the everyday politics of citizenship struggles by Jakarta's urban poor.

A revelatory approach to floods helped me to show that disasters such as floods create a moment of shock in which new opportunities arise, for all actors involved. Urban planners can use floods to push an agenda of modernisation; at the same time, floods can generate media attention and the support of unknown groups of residents. Each of these dynamics may set in motion a tipping of the power balance in a given society. In this case, the notion of juxtaposition helped me to tease out the gradually shifting ideas and practices of citizenship, most notably the rights to housing and compensation. My findings underline observations of scholars such as Chatterjee (2004), Yiftachel (2012), Bénit-Gbaffou and Oldfield (2014) and Millstein (2017) and others, that different types of citizenship co-exist in different contexts around the world, including differentiated ideas and practices of city-making. It contributes to the literature of citizenship by focusing on everyday citizenship practices, which enables to recognise both formal and informal, traditionally participatory and innovative 'rights' practices. As such, the paper moves beyond earlier descriptions of how the urban poor claim rights, where these were described as insurgent or alternative. Rather, in my 
analysis, the urban poor take up a wide range of practices and strategies, which could be categorised in many different ways. The court case examined is an example of a political-institutional pathway towards claiming rights; the many informal negotiations, exchanges with media in an aim to change the social norm and gain support, and the protests in the neighbourhood are all examples of more innovative citizenship practices.

The paper also shows that practices evolve, as people learn (something which Savirani and Saedi (2017) call 'internal factors') and as social, political or economic contexts change (external factors). Regarding the latter, in Jakarta, the changing political context, in which a new governor-later president-took a new approach towards the urban poor, influenced the ways in which residents and organisations could mobilise themselves in a countermovement. Jokowi's active engagement with civic and urban poor organisations enabled these parties to find an opening - albeit rather restricted - into decision-making processes. Due to the promises made during the election campaigns, and due to the media attention for these promises, it became easier to pressure against policies after promises were broken. The result was that these organisations, and the community they represented, were left with a greater repertoire of influencing. They did not have to stick to informal citizenship practices, such as patronage or protest, but also dared to mobilise influential outsiders (media, architects, activist researchers) and started a court case. This means that for this case, the concepts of protest or insurgency would be too limited. It seems more fruitful to speak of a range of mixed citizenship practices, or even of limited political citizenship. ${ }^{3}$

Tracing dynamics within and around a flood-prone and eviction-prone riverbank settlement in Jakarta, it became clear that floods and flood policies were both maintaining and worsening already-existent inequalities and divisions, but also worked as a catalyst for people to contest these. The article perceived floods and disaster policies in Jakarta as events that have deepened divides between the city's elite (those who can afford housing that is safe from floods, and who have access to land tenure and to formal citizens' rights) and the poor (who are generally vulnerable to both floods and evictions and forced to defy policies that are implemented from above). However, the analysis revealed that floods and evictions also allowed for the urban poor to make new claims for citizenship, such as the right to have a house, or to be compensated for that house after evictions. This accords with the conclusion that was already drawn by James Holston (2009, 2011), namely, that whilst ongoing urbanisation has worsened poverty and inequality in cities worldwide, the struggles of low-income or otherwise marginalised residents for the basic resources of daily life and shelter have also generated new ideas and practices of citizenship. But again, these do not just entail 'alternative' practices, but also participation practices.

Of course, it remains to be seen whether the residents from my study will eventually be compensated. Regarding the fact that the evictions were supported by a large part of the Jakartan (middle class and elite) voters, and the fact that in the past, court cases about land rights of riverbank settlers against the government were lost again and again (Van Voorst 2014); unfortunately, there still exists a fair chance that they will not succeed. However, at the same time, it seems that the process has shifted somewhat the power balance in the city of Jakarta. Marginal groups have been able to strengthen their social capacity; they have gained access to relevant knowledge, financial resources and

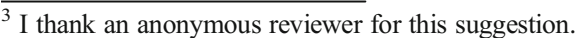


a useful network of academic and media actors. It is likely that these groups will enjoy the fruits of these gains in their future work and life, for example when other evictions will eventually take place in Jakarta. Moreover, all informants that I have spoken to over the past years describe a strengthened feeling of agency. One example was the WhatsApp group, through which slum dwellers started to communicate with academics, journalists, activists and other relatively powerful outsiders. Together, they formulated demands, gained access to academic knowledge about land rights and human rights and tried to engage with the governor and other powerful stakeholders - sometimes with success, and always with a new and more positive experience about what might be possible regarding claiming housing rights, as poor slum dwellers. Whilst urban divides between the poor and the elite, the informal and the formal were not wrecked; they were certainly blurred.

Authors' Contributions All texts were written by the main author.

Funding Information This research was funded by NWO, grant number 453-14-013.

Data Availability The data is contained in the database of Erasmus University.

\section{Compliance with Ethical Standards}

Conflict of Interest The author declares that there is no conflict of interest.

Code Availability Not applicable.

Open Access This article is licensed under a Creative Commons Attribution 4.0 International License, which permits use, sharing, adaptation, distribution and reproduction in any medium or format, as long as you give appropriate credit to the original author(s) and the source, provide a link to the Creative Commons licence, and indicate if changes were made. The images or other third party material in this article are included in the article's Creative Commons licence, unless indicated otherwise in a credit line to the material. If material is not included in the article's Creative Commons licence and your intended use is not permitted by statutory regulation or exceeds the permitted use, you will need to obtain permission directly from the copyright holder. To view a copy of this licence, visit http://creativecommons.org/licenses/by/4.0/.

\section{References}

Appadurai, A., Breckenridge, L. A., Nutall, S., \& Mbembe, A. (2008). Johannesburg: the elusive metropolis. Duke University Press.

Bénit-Gbaffou, C., \& Oldfield, S. (2014). Accessing the state: Everyday practices and politics in cities of the south. Journal of Asian and African Studies, 46, 445-451.

Chatterjee, P. (2004). Politics of the governed. New York: Colombia University Press.

Cohen, N., \& Margalit, T. (2015). There are really two cities here: fragmented urban citizenship in Tel Aviv. Journal of Urban and Regional Research.

De Boeck, F., \& Plissart, M. F. (2004). Kinshaha: Tales of the Invisible City. Ghent: Ludion.

Hammar, A., \& Millstein, M. (2016) Juxtacities: producing authorities and citizenship through urban divides. Concept note for Juxtacities special issue.

Hellman, J. (2015). Living with floods and coping with vulnerability. Disaster Prevention and Management, 24(4), 30-40. 
Hellman, J., Thynell, M., \& R. van Voorst. 2018. Introduction: Shaping Jakarta. In: Jakarta: Claiming Spaces and Rights in the City, Hellman, J., Thynell, M., \& R. van Voorst (Eds.). London: Routledge.

Holderness, T. \& Turpin, E. (2015) White paper - PetaJakarta.org: assessing the role of social media for civic co-management during monsoon flooding in Jakarta, Indonesia. https://petajakarta.org/banjir/en/research/ accessed 13 February 2020.

Holston, J. (2008). Insurgent citizenship. Princeton University Press.

Holston, J. (2009). Insurgent citizenship in an era of global urban peripheries. City \& Society, 21, $245-267$.

Holston, J. (2011). Contesting privilege with right: The transformation of differentiated citizenship in Brazil. Citizenship Studies, 15, 335-352.

Millstein, M. (2017). Rights, identities and belonging: reflections on the everyday politics of urban citizenship in Delft, Cape Town. Norsk Geografisk Tidsskrift/Norwegian Journal of Geography, 71(4), 253-267.

Miraftab, F., \& Wills, S. (2005). Insurgency and spaces of active citizenship: the story of Western Cape AntiEviction Campaign in South Africa. Journal of Planning Education and Research, 25, 200-217.

Savirani, A., \& Saedi, E. (2017). Juggling while claiming rights. The urban poor Community in North Jakarta. In E. Hiariej \& K. Stokke (Eds.), Politics of Citizenship in Indonesia (pp. 177-200). Jakarta: Yayasan Pustaka Obor Indonesia.

Shepherd, A. (2015) Update on evictions. ACHR Website. http://www.achr.net/extra.php?ic=16 Accessed 13 February 2020.

Simone, A. (2010). Movements at the crossroads. Urbanization from Jakarta to Dakar. New York: Routledge.

Simone, A. (2011). The surfacing of urban life: a response to Colin McFarlane and Neil Brenner. City, 15(34).

Solway, J. S. (1994). Drought as a 'revelatory crisis': an exploration of shifting entitlements and hierarchies in the Kalahari, Botswana. Development and Change, 25(3), 471-495.

The Jakarta Post, 2015a. If only Ahok would listen.http:/www.thejakartapost.com/news/2015/08/22/editorialif-only-ahok-would-listen.html Accessed 13 February 2020.

The Jakarta Post, 2015b. Kampung Pulo preparing for legal suit. http://www.thejakartapost.com/news/2015/08 /22/kampung-pulo-preparing-legal-suit.html Accessed 13 February 2020.

Törnquist, O., \& Djani, L. (2017). Stalemated populism and the case for citizenship-driven social democracy. Juggling while claiming rights. The urban poor Community in North Jakarta. In E. Hiariej \& K. Stokke (Eds.), Politics of Citizenship in Indonesia (pp. 85-118). Jakarta: Yayasan Pustaka Obor Indonesia.

Van Voorst, R. S. 2014. Natural hazards, risk and vulnerability: floods and slum life in Indonesia. London: Routledge.

Wilson, I. (2015). The politics of flood alleviation in Jakarta. Newspaper article in The Jakarta Post, (09 May).

Yiftachel, O. (2012). Between colonialism and ethnocracy: Creeping apartheid in Israel/Palestine. Johannesburg: Afro-Middle East Centre.

Publisher's Note Springer Nature remains neutral with regard to jurisdictional claims in published maps and institutional affiliations. 